\author{
광릉늑대거미 (Arctosa kwangreungensis) 배후발생과정의 \\ 조직 미세구조 분석 \\ 양 성 찬, 문 명 진* \\ 단국대학교 생명과학과
}

\title{
Histologic and Microstructural Analyses on Postembryonic Development in the Wolf Spider Arctosa kwangreungensis (Araneae: Lycosidae)
}

\author{
Sung-Chan Yang, Myung-Jin Moon* \\ Department of Biological Sciences, Dankook University, Cheonan 330-714, Korea \\ (Received February 15, 2012; Revised March 26, 2012; Accepted March 26, 2012)
}

\begin{abstract}
Histologic and microstructural changes during the postembryonic development of the wolf spider Arctosa kwangreungensis were studied using light and scanning electron microscopy to examine the relationship between a morphological differentiation and behavioral properties. The postembryo with abdominal yolk sac was stayed inactive in the egg case because its muscular and visual systems were not fully developed to a functional level. The first instar spiderlings, developed from the postembryo by a first molting process, started to exhibit its pigmentation on their body cuticles. In particular, undifferentiated cell clusters of central nervous system (CNS) were densely distributed within the cephalothorax, and highly differentiated abdominal ganglion was observed. They had a characteristic visual system looks more like its adult counterpart, and had segmented appendages looks more like the tiny spiders containing well oriented muscular system. After 3rd instar, spiderlings grew more rapidly with accordance to their consistent growth and periodical molting processes. Thus, the relative area of CNS with respect to cephalothorax was gradually decreased, instead a pair of venom glands, musculature, and connectives occupied the residual area. It has been revealed that the early development of spider can be controled by the feeding condition of larval period, since histologic and microstructural differentiations in both appendages and optic system were completed at the second instar. In particular, behavioral properties of the wandering spiders that depend on vision and their running ability were deeply related to physiological differentiation of the microstructural development.
\end{abstract}

Keywords : Microstructure, Postembryonic development, Spider, A. kwangreungensis

서 론

늑대거미과(Lycosidae)에 속하는 배회성 거미는 전 세계
에 걸쳐 약 3,000 종(국내 7속 47종) 이상이 서식하고 있음 이 보고되어 있다(Im \& Kim, 2000). 행동학적으로 늑대거미 암컷은 알주머니를 복부 끝 실젖에 매달고 다니는 독특한

* Correspondence should be addressed to Myung-Jin Moon, Department of Biological Sciences, Dankook University, Cheonan 330-714, Korea. Ph.: (041) 550-3445, Fax: (041) 550-3409, E-mail: moonmj@ dankook.ac.kr 
습성을 지니고 있으며 (Buddle, 2000), 부화된 거미 유충들은 일정 기간 동안 어미의 등에 업혀 생활하게 되는데(Eason \& Whitcomb, 1965), 이와 같은 행동습성으로 인해 모성 본 능이 매우 강한 종류로 알려져 있다(Kim, 2002).

거미 발생단계의 구분은 연구자에 따라 다양한 기준이 적 용되고 있으며, 난각(chorion)을 깨고 나온 단계를 후기배아 (postembryo)로 규정하거나 또는 이를 제1령 유충(first instar) 단계로 규정하는 등 발생 단계의 구분에 대한 혼란이 심각 한 수준이다. 또한 일부 연구자들은 prelarva, larva, lymph 등 의 다양한 용어를 도입함으로써 더욱 혼란을 가중시키기도 하였다(Foelix, 2011). 따라서 이러한 발생단계에 따른 혼란 을 피하기 위해 자체적인 기준을 제시한 경우도 있었고(Liu et al., 2009), 또한 최근에는 이러한 논쟁을 해결하기 위하여 거미강(Arachnid)에 속하는 여러 분류군의 발생단계를 종합 하여 합리적인 기준을 제시하려는 시도도 있다(Robert, 2005).

거미의 발생에 관한 연구는 많은 부분이 거미류의 생태나 행동 연구와 관련되어 활발한 연구가 이루지고 있으며(Balázs \& Ferenc, 2002; Laurie \& John, 2008), 형태학적인 접근으로 는 주로 독선(Jacqueline \& Arturo, 1995)이나 색소세포(Teresita \& Jerome, 2008)의 발생이나, 부속지 감각모의 발생 (Stollewerk \& Seyfarth, 2008)에 대한 연구가 있다. 최근 McGregor et al. (2008)은 거미의 진화와 발생에 관하여, Liu et al. (2009)은 후기 발생단계에서 배아의 부속지 발달에 관하여 형태학적 접근을 시도하였으며, Wolf \& Hilbrant (2011)은 늑 대거미의 초기 발생단계를 형태학적으로 구분한 바 있다.

이처럼 다양한 영역에서 거미의 발생과정이 연구되고 있 지만, 여전히 한 종의 완전한 발생을 이해하기에는 부족한 부분이 많고, 특히, 배회성 거미의 초기 배후발생과정에 대 해서는 명확하게 밝혀지지 않은 바가 많고 초기 행동학적 연관성도 확실히 규명되지 않은 부분이 많은 실정이다. 따 라서 본 연구는 배회성거미류를 실험재료로 초기 발생단계 를 구분하고 배후발생단계에서 관찰되는 조직학적 및 미세 구조적 특성 분석을 통하여 기존에 알려진 행동학적 측면 을 고찰하였으며, 이를 통하여 거미의 형태적 발달과 행동 학적 발달과의 연관성을 밝히고자 하였다.

\section{재료 및 방법}

본 연구는 절지동물문(Arthropoda), 거미강 (Arachnida), 거미목(Araneae), 늑대거미과(Lycosidae)의 광릉늑대거미 (Arctosa kwangreungensis)를 사용하여 실험하였다. 2011년 7월부터 10월 사이에 단국대학교 천안캠퍼스 인근 지역에 서 채집된 암수 성체들 중 알주머니를 가진 암컷 성체를 선 별하여 실험실로 옮기고 안정화시켜 실험에 사용하였다. 각 각의 개체를 작고 투명한 사육조 속에 격리시킨 후, 매일 2
회 적정량의 수분과, 어리쌀도둑거저리 (Tribolium confusum) 유충을 먹이로 공급하여주며 사육하였다. 사육한 유충들은 알주머니로부터 부화되고 탈피를 진행하는 과정에 따라 각 단계별로 시료를 추출하여 실험을 진행하였다. 암컷의 등 위 에 업혀서 보호받는 기간이 끝나고 분산이 이루어지기 시작 한 유충들은 원통형 사육조에 수용하여 인공 사육을 계속 하였으며, 탈피가 이루어진 시점을 기준으로 발생 단계를 구분하여 실험재료로 사용하였다.

발생 단계별로 선별된 시료들은 이산화탄소를 이용하여 마취시킨 후 희생시킨 다음, 해부현미경 하에서 해부용 가위 로 복부를 분리하고, 두흥부에 있는 네 쌍의 다리와 한 쌍의 더듬이다리(pedipalpi)도 함께 제거하였다. 시료 처리가 진 행되는 동안 거미의 체액 상태를 유지하기 위하여 거미 생 리식염용액 (spider Ringer's solution: $160 \mathrm{mM} \mathrm{NaCl}, 7.5 \mathrm{mM}$ $\mathrm{KCl}, 4 \mathrm{mM} \mathrm{CaCl}_{2}, 1 \mathrm{mM} \mathrm{MgCl}, 4 \mathrm{mM} \mathrm{NaHCO}_{3}, 20 \mathrm{mM}$ glucose, $\mathrm{pH}$ 7.4) (Groome et al., 1991)을 사용하여 해부하였다.

광학현미경을 이용한 조직관찰 시료는 부황용액 (Bouin's fixative)을 제조하여 24시간 동안 충분히 고정하였다. 고정 이 완료된 시료는 흐르는 물로 약 2 시간 동안 수세하여 여 분의 고정액을 제거한 후, ethanol 농도상승 순으로 $(70 \%$, $80 \%, 90 \%, 95 \%, 100 \%)$ 처리하여 탈수하였다. 탈수된 시료 는 xylene 용액으로 치환하여 투명화(clearing) 처리한 후, Paraplast Plus Medium (Fisher Scientific Co., USA)을 이용 하여 포매 (embedding)하였다.

포매된 시료는 RM-2135 조직절편제작기(Leica, Germany) 를 사용하여 $5 \mu \mathrm{m}$ 두께의 절편을 만들어 슬라이드에 부착시 킨 후, xylene 용액을 사용하여 조직에 침투한 파라핀을 제 거하였다. 이어서 ethanol 농도하강 순으로 $(100 \%, 95 \%, 90 \%$, $80 \%, 70 \%$ ) 친수화 처리시킨 후, hematoxylin-eosin (H-E) 용액 으로 이중 염색하여, Nikon 80i 광학복합현미경 (Nikon, Japan) 으로 관찰하고 디지털 파일의 형태로 화상을 저장하였다. 또한 관찰 시료에 대한 정밀한 계측과 구조 해석을 위하여 Motic Image Analysis Program (Motic Instruments Inc., Canada) 을 이용한 다각적인 화상분석도 병행 실시하였다.

주사전자현미경 관찰을 위한 시료는 형태 변형을 방지하 기 위하여 $0.1 \mathrm{M}$ phosphate buffer $\left(4^{\circ} \mathrm{C}, \mathrm{pH}\right.$ 7.4)로 완충시킨 $2 \%$ paraformaldehyde와 $2.5 \%$ glutaraldehyde 혼합용액 (Karnovsky, 1965)을 제조하여 고정 처리한 후, 동일 완충용액으 로 3회 수세하였다. 수세된 시료는 $0.1 \mathrm{M}$ phosphate buffer $\left(4^{\circ} \mathrm{C}, \mathrm{pH}\right.$ 7.4)로 완충시킨 $1 \%$ osmium tetroxide 용액으로 후 고정한 후, 동일 완충용액을 사용하여 충분히 세척하였다.

고정이 끝난 시료는 ethanol 농도상승 순 $(30 \%, 50 \%, 70 \%$, $90 \%, 95 \%, 100 \%)$ 으로 처리하여 탈수하였으며, 탈수된 시료 는 hexamethyldisilazane (HMDS) 용액으로 처리한 다음, 자 연건조 처리하였다. 준비된 시료는 stub에 부착하고, E-1030 sputter coater (Hitachi, Japan)를 사용하여 약 $20 \mathrm{~nm}$ 두께로 
백금 도금한 후, Hitachi-4300 FESEM 주사전자현미경 (Hitachi Co., Japan)으로 5 $15 \mathrm{kV}$ 의 가속전압에서 관찰하고, 촬영된 이미지들은 디지털 파일의 형태로 화상 처리하여 분석에 사 용하였다.

\section{결 과}

광릉늑대거미의 배아 및 유충(instar)의 발생 단계에 따른 외부 형태의 변화를 광학현미경 및 주사전자현미경을 이용 하여 비교한 결과, 초기 발생단계는 알주머니 내부에서 진행 되는 후기배아 및 초기유충 단계(제1령 유충), 그리고 알주 머니를 벗어난 이후의 후기유충 단계(제 2 령 유충, 제 3 령 유 충 등)로 구분되었다. 거미 발생단계의 구분은 난각(chorion) 을 깨고 부화된 단계를 후기배아(postembryo)로, 첫 번째 탈 피과정을 통해 출현한 유충단계를 제 1 령 유충(first instar)으
로, 그리고 두 번째 탈피과정을 거쳐 알주머니를 벗어난 단 계를 제2령 유충(second instar)으로 규정하였다.

해부현미경을 사용하여 알주머니 내부에서 발생중인 배 아의 외부 형태적 특징을 관찰한 결과, 이들은 성체 암컷 성 체 난소에서 발생중인 미산란 상태의 알들과 현저한 차이를 보였다. 미수정란은 수정과정을 거쳐 담황색의 수정란으로 변화되었고 난각을 지닌 상태로 알주머니 속에 산란되었다 (Fig. 1A, B). 발생중인 배아는 주로 부속지의 발생단계에 따 라 형태적 구분이 가능하였는데, 난각 속에서 발생중인 배아 들은 두흥부와 복부영역의 구분이 가능하였고, 두흉부에서 는 부속지의 원기들이 관찰되었다(Fig. 1C). 이 후 발생이 진행될수록 두흉부의 색상이 옅어져 담황색에서 백색으로 변화되었으며, 각 부속지의 마디구조도 명확하게 구분되었 다(Fig. 1D).

난각을 깨고 부화되어 나온 후기배아는 외형상 성체와 유 사한 형태를 하고 있었고 현미경 시야에서 미세한 움직임이
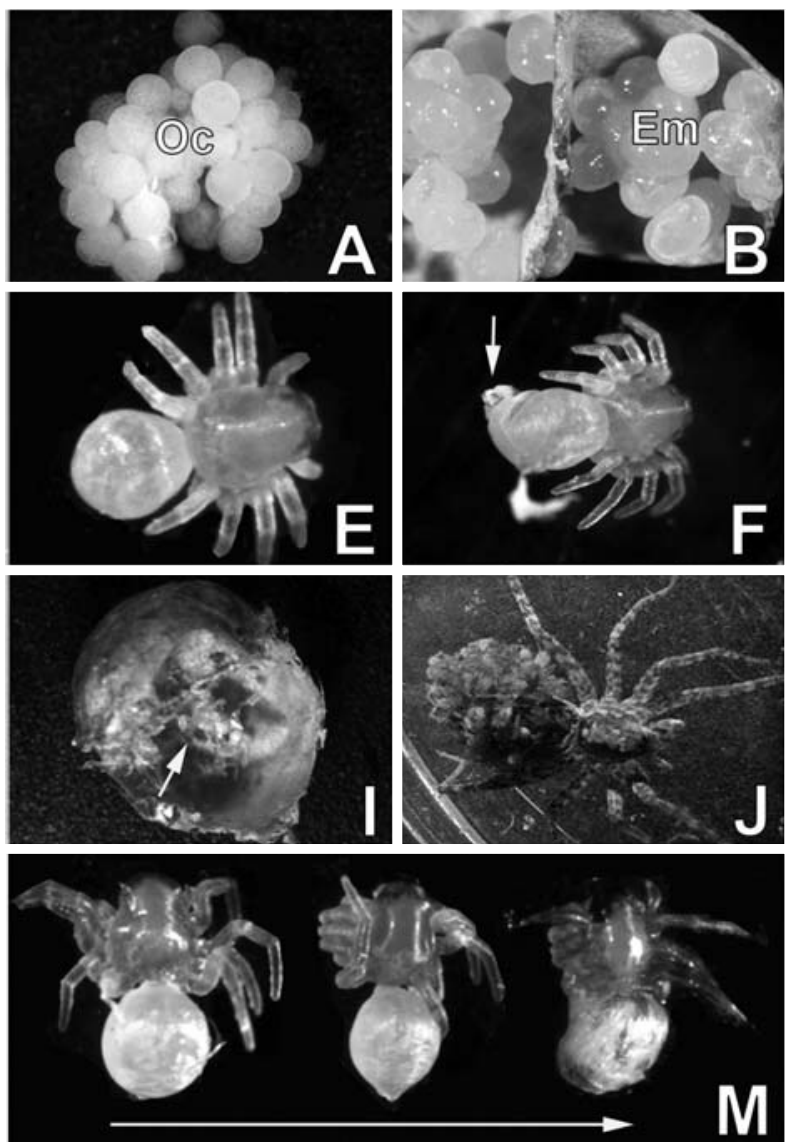
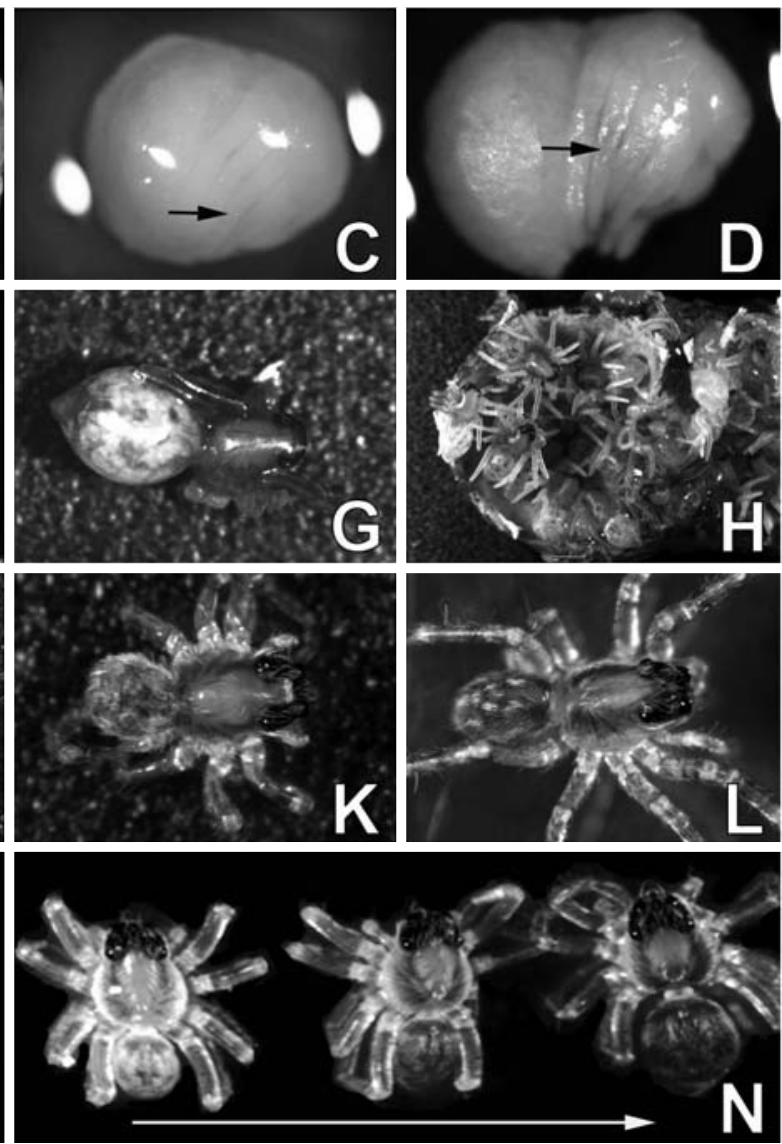

Fig. 1. Postembryonic development in A. kwangrungensis. A-H: Development within egg case. A: Ovarian eggs (Oc) from adult female spider. B: Fertilized eggs (Em) within egg case. C, D: primitive appendages (black arrow) developed in early embryo. E, F: Residual chorion (white arrow) of postembryo (Po) at eclosion. G: First instar (1st) spiderling. H: First instar spiderlings within egg case. I-L: Development after emerging from egg case. I: Empty egg case after escape of the second instar spiderlings. White arrow indicates exoskeletons formed by the second molting process. J: The second instar spiderlings (black arrow) climbing on to their mother. K: Second instar (2nd) spiderling at ten days after hatching. L: third instar (3rd) spidering after the 3rd molting process. M: Early development within egg case from postembryo (Po) to second instar (2nd). N: Development after escape egg case from second instar(2nd) to forth instar (4th). 
관찰되었다. 후기배아는 담황색의 복부마디와 회색의 두흉 부로 이루어져 있었으며, 복부마디는 여분의 난황물질을 함 유하여 팽창된 모습으로 관찰되었다(Fig. 1E). 부화 직후의 후기배아에서는 체표면에 부착되어 파쇄된 난각의 잔여체 도 관찰되었다(Fig. $1 \mathrm{~F})$.

알주머니 속의 후기배아는 최초의 탈피과정을 거쳐 움직 임이 활발한 제1령 유충으로 발생되었는데, 이 시기에 색소 화반응(melanization)에 의해 두흥부의 색상 변화가 현저해 지고, 독특한 복부의 문양이 형성되었다. 두향부의 갑각 (carapace)에서는 두흉부의 크기에 비해 상대적으로 대형인 8개 의 단안들이 확인되었으나 성체와는 달리, 큐티클 표면으로 돌출된 렌즈구조는 관찰되지 않았다(Fig. $1 \mathrm{G}$ ). 부화 직후의 제1령 유충들은 알주머니의 실크 구조물 속에서 비활성 상 태를 유지하며, 또한 두흉부가 알주머니 중심부를 향하고 있는, 방사상의 배열을 유지하고 있음이 확인되었다(Fig. 1H).

알주머니 속에서 최초의 탈피과정을 끝낸 제 1 령 유충들 은 이후 한 차례의 추가적인 탈피를 통해 제 2 령 유충으로 발생되었다. 이 상태에서 알주머니의 실크를 찢고 밖으로 나온 후 어미의 등에 올라 보육을 받게 되는데, 유충이 빠 져 나간 알주머니에서는 탈피 잔여체 (exoskeleton)가 확인 되었다(Fig. 1I). 알주머니 밖으로 나온 제2령 유충들은 어 미의 등위에서 머무르다 평균 7일을 전후하여 분산되었다 (Fig. 1J). 제2령 유충의 체표에는 강모가 형성되고 담황색에 서 갈색으로 체색 변화가 진행되었으며 복부 난황의 소실 로 인해 복부 영역이 상대적으로 축소되었다. 두향부도 색 이 짙어지고 고유의 체표 문양이 선명하게 발현되었고, 후 기배아나 제 1 령 유충 단계와는 달리 큐티클 표면으로 렌즈 가 돌출되어 시각기 구조가 관찰되었다(Fig. $1 \mathrm{~K})$.

제3령 시기에는 다리에 긴 강모가 나타나기 시작하였으 며, 활발한 섭식작용을 통해 체색 변화가 더욱 현저하게 진 행되어 짙은 갈색의 체색이 발현되었다. 제 3 령 유충 시기 이 후의 배후발생과정은 탈피를 거듭하며 개체의 크기가 증가 하고 체색이 짙어지는 특성을 제외하면 현저한 형태적 변화 는 관찰되지 않았다 (Fig. $1 \mathrm{~L}$ ). 즉, 광릉늑대거미의 초기 배후 발생과정은 알주머니 내부의 후기배아, 제 1 령 유충으로 구분 되고(Fig. $1 \mathrm{M})$, 알주머니를 벗어난 제2령 유충부터 섭식을 시작하고 성장이 빨라지고 주기적인 탈피과정을 거쳐 지속 적인 발생이 이루어지는 것으로 관찰되었다(Fig. $1 \mathrm{~N}$ ).

광릉늑대거미 초기 발생단계의 배아 및 유충들을 고해상 도의 주사전자현미경으로 관찰한 결과, 두흥부와 복부 영역 의 구별이 가능해 지는 단계의 배아에서는 두흉부 영역에서 부속지의 원기가 관찰되었는데, 4 쌍의 부속지 (appendages) 와 1 쌍의 더듬이다리 (pedipalpi)가 명확히 구분되었다(Fig. $2 \mathrm{~A})$. 또한, 배아 단계의 개체는 복부에 함유되어 있는 난황 으로 인해 복부의 영역이 차지하는 비율이 두흉부에 비해 높게 관찰되었다(Fig. 2B). 발생이 진행될수록 복부의 영역
이 축소되면서 두흥부와의 경계가 명확해지고, 난각 내부에 접혀있던 부속지도 확장되어 이를 기준으로 초기 단계의 배 아를 구분할 수 있었다(Fig. 2C). 발생중인 부속지는 배아의 정중면을 기준으로 좌우 대칭을 이루고 있었고, 세부적으로 부속지의 분절구조가 확연히 구분되었다(Fig. 2D).

부화과정을 통해 난각을 벗어나는 시기의 후기배아에서는 두흥부로부터 파쇄가 진행되는 난각의 미세구조가 확인되었 고 후기배아의 체표구조도 명확히 관찰되었다(Fig. 2E). 후 기배아는 난각을 벗기 이전에 이미 성체와 동일한 체형으 로 발생을 완성하였으며, 난황으로 인해 팽대된 복부의 구 조와 분절구조를 지닌 부속지들을 지니고 있었다(Fig. 2F). 난각을 벋어난 후기배아의 체표에는 강모가 거의 없어 부 드럽고 탄력있는 구조를 형성하고 있었고, 두흉부의 상당부 분을 차지하는 편평한 시각기 구조와 짧은 부속지를 지니 고 있음이 확인되었다(Fig. $2 \mathrm{G}$ ). 알주머니를 벗어나 활발한 먹이활동을 하는 제 3 령 유충에서는 신장된 부속지와 돌출 된 렌즈구조를 지닌 발달된 시각기가 관찰되었다. 또한 복 부 난황이 소실되어 두흉부에 비해 확연히 축소된 복부마 디와 함께 체표와 부속지의 표면에서는 잘 발달된 강모들 이 관찰되었다(Fig. $2 \mathrm{H}$ ).

초기 발생에 따른 조직학적 변화를 분석하기 위하여 후기 배아 시기부터 성체에 이르기까지 각 발생 단계의 두흥부에 대한 관상단면을 제작하여 관찰한 결과, 중추신경계의 발생 에 따른 기관계의 분화과정이 확연히 구분되었다. 후기배아 시기의 두흉부에는 신경절의 분화가 미약한 중추신경계를 중심으로 신경섬유와 다수의 신경세포들이 분포되어 있었 다. 한 쌍의 독선의 발생은 이미 기능적 단계에 도달하였지 만, 시각신경절(optic ganglion)과 시각신경 (optic nerve)의 발 생과 체내 근육조직의 발달은 상대적으로 매우 미약하였다. 특히, 각 부속지신경절 (appendage ganglion)과 연결되는 신경 섬유의 경계가 명확하게 구분되지 않았고 신경섬유의 발달 도 미약하였다(Fig. 3A). 시상면으로 관찰한 후기배아의 두 흥부에서는 시각기의 미분화로 인해 중추신경계로부터 분지 된 시각신경절과 시각신경계의 분화가 매우 미약하고 신경 섬유의 일부와 미분화된 세포 핵들이 분산되어 관찰되었다 (Fig. 3B).

제1령 유충의 두흉부는 후기배아 시기에 비해 중추신경계 의 영역이 보다 확장된 형태로 나타났으며, 식도하신경절 (subesophageal ganglion)에서 각 부속지신경절로 분지되는 신경섬유가 증가되어 신경절 사이의 경계부도 명확히 구분 되기 시작하였다. 특히 복부신경절 (abdominal ganglion)과 연결되는 영역에서 급격히 증가된 세포집단이 관찰되고, 또 한 두흥부와 연결된 부속지의 경계도 명확하게 구분되었다 (Fig. 3C).

제2령 유충의 두향부는 이전 시기의 유충과는 달리, 근육 조직이 매우 발달되었고, 중추신경계를 구성하는 신경섬유 

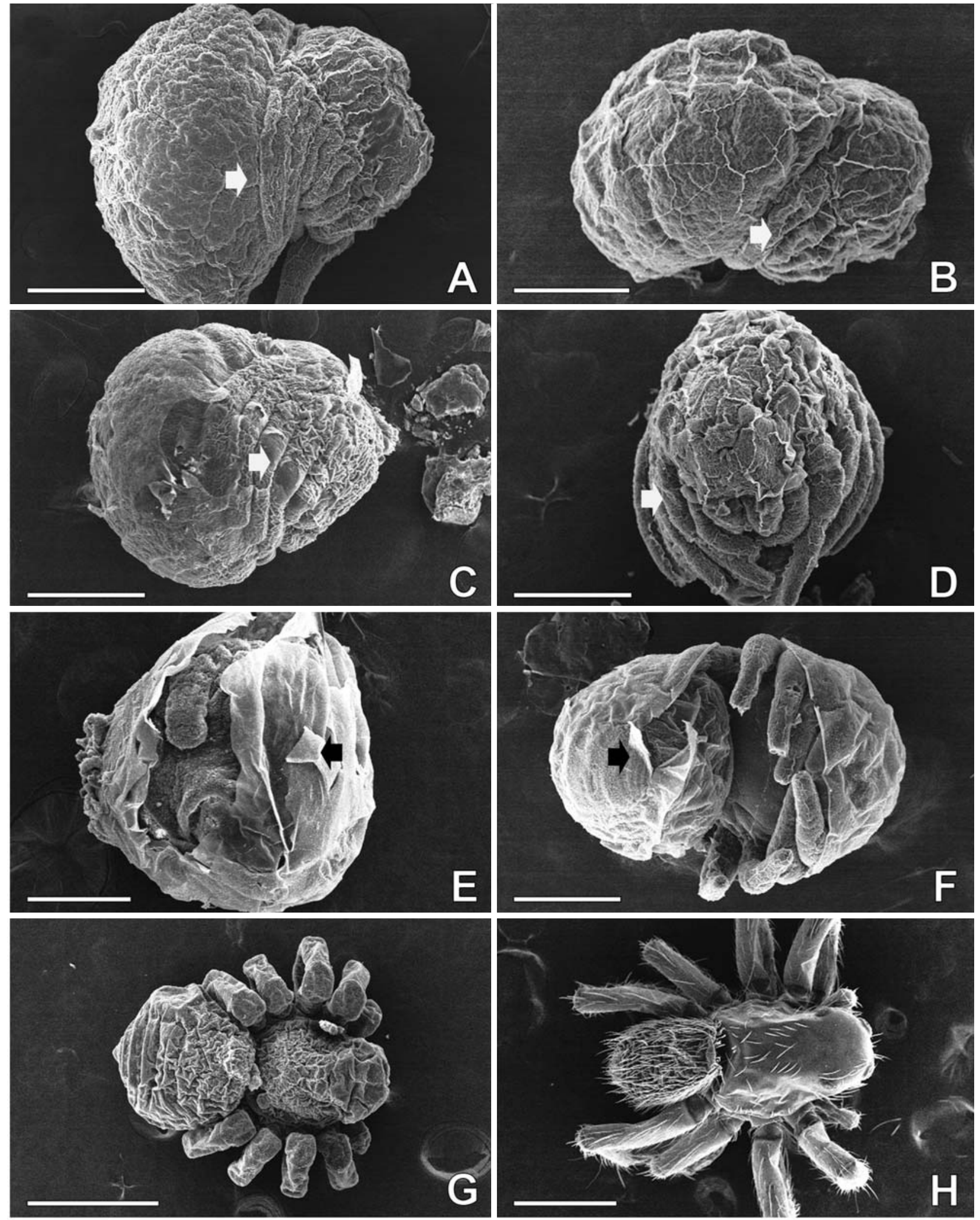

Fig. 2. Scanning electron micrographs of the early development in A. kwangrungensis. A-D: Microstructure of unhatched embryo. White arrow indicates primitive appendages of the embryo. Note the chorion (black arrow) wrapping the surface of embryo. E, F: Postembryo after rupturing its chorion. G: Postembryo out of chorion. H: Third instar spiderlings after emerging from egg case. At this stage, they have segmented appendages and pigmented body with surface bristles. Scale bar indicates $200 \mu \mathrm{m}(\mathrm{A}) 250 \mu \mathrm{m}(\mathrm{B}-\mathrm{F})$ and $500 \mu \mathrm{m}(\mathrm{H})$. 

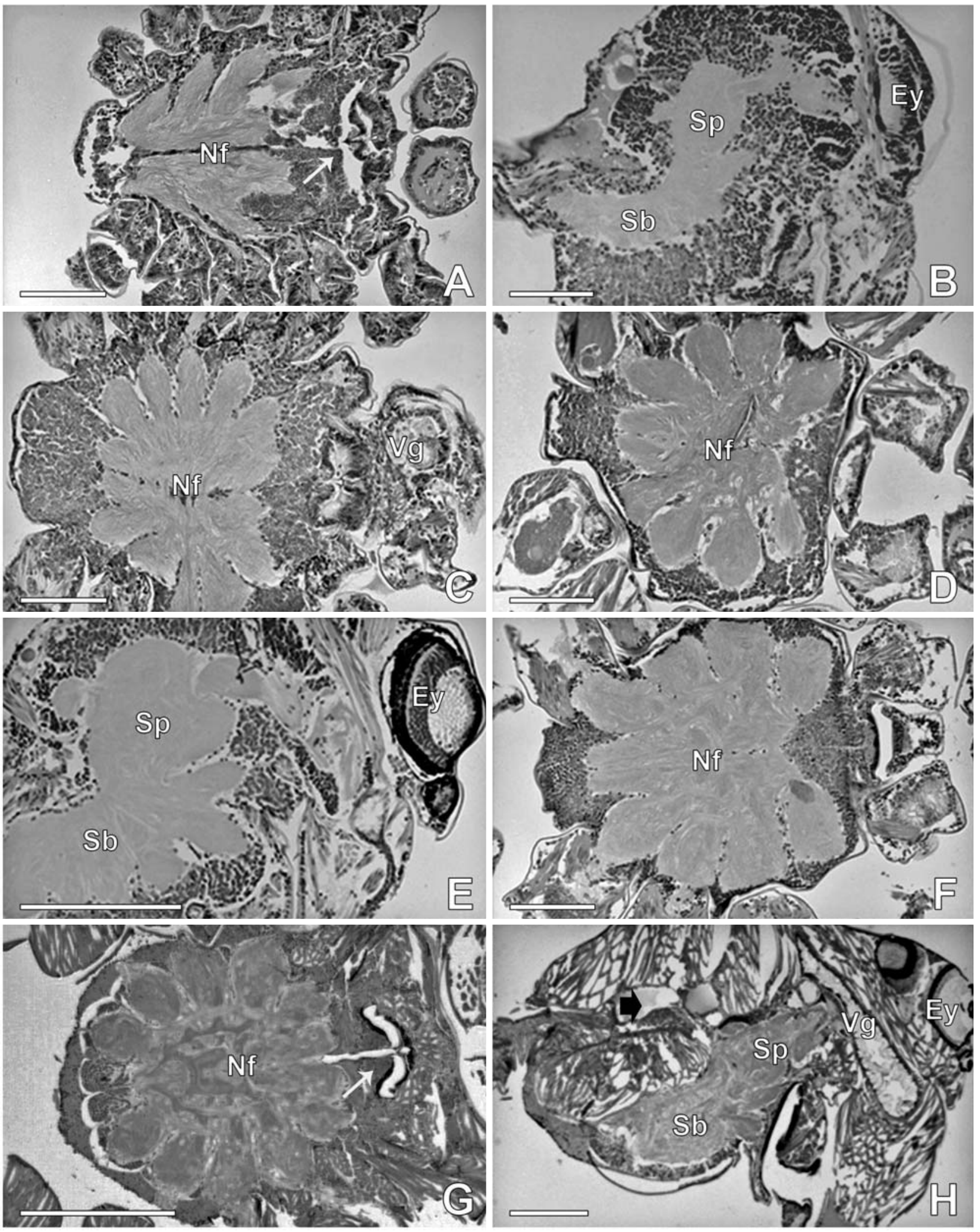

Fig. 3. Light micrographs of developing spiderlings in A. kwangrungensis by histologic preparation. A: Frontal section of postembryo. B Sagittal section of postembryo. C: First instar. D: Frontal section of second instar. E: Sagittal section of second instar. F: Third instar. G: Frontal section of adult spider. H: Sagittal section of adult spider. Black arrow: diverticulum. Ey: eye. Nf: neural fiber. Sb: subesophageal ganglion. Sp: supraesophageal ganglion, Vg: venom gland, Scale bar indicates $200 \mu \mathrm{m}(\mathrm{A}-\mathrm{F})$ and $500 \mu \mathrm{m}(\mathrm{G}, \mathrm{H})$. 
의 수가 급격히 증가되었음이 관찰되었다. 부속지의 분절구 조가 완성되어 근육조직과 신경계로 채워져 있었으며 부속 지신경절과 연결되는 신경섬유의 다발도 팽대된 형태로 관 찰되었다(Fig. 3D). 이 시기에 시각기의 발생이 완료되어 성 체와 동일한 조직학적 체제가 완전히 구축되었고, 시각신경 절로부터 분지된 시신경의 다발도 현저하게 발달되어 있음 이 확인되었다. 또한 시각신경절이 발달함에 따라 이와 연결 된 식도상신경절(supraesophageal ganglion)의 영역이 매우 확장된 모습으로 관찰되었다(Fig. 3E).

제 3 령 유충의 두흥부 대부분은 중추신경계의 신경섬유와 세포핵의 집단으로 채워져 있었고, 조직학적 체제로 보았을 때 성체와 거의 유사한 상태로 발생이 진행되었음을 확인할 수 있었다. 각 신경절 사이의 경계가 명확히 구분되었고, 구 성하는 신경섬유의 분지방향에 따라 성체와 동일한 신경섬 유 다발 (fiber tract)들이 확연히 구분되었다(Fig. 3F).

광릉늑대거미 성체의 두흥부는 유충들과 달리 신경섬유 다발이 매우 발달되어 있는 반면, 세포핵의 집단이 차지하 는 영역은 매우 축소되어 몇몇 영역에서만 제한적으로 관찰 되었다. 근육조직은 매우 발달되어 체표의 큐티클과 연결된 근육의 다발들이 광범위하게 분포되어 있고 중추신경계를 관통하는 소화관의 영역도 구분되었다. 신경섬유 다발의 특 이적인 배열과 팽대된 부속지 신경절로부터 분지되는 신경 섬유들도 명확히 구분되었다(Fig. $3 \mathrm{G}$ ). 시상면으로 보았을 때 중추신경계가 두흉부에서 차지하는 영역은 이전 시기의 유충들에 비해 매우 축소되고, 나머지 영역은 한 쌍의 독선 과 근육조직, 그리고 결합조직 등으로 채워져 있음이 관찰 되었다. 특히, 유충 단계에서 집단적으로 광범위하게 관찰되 었던 미분화상태의 세포핵들이 거의 사라지고 일부 영역에 서만 제한적으로 남아 있음이 확인되었다(Fig. $3 \mathrm{H}$ ).

발생단계에 따른 광릉늑대거미 유충의 형태적 변화를 정량 분석하기 위하여 두흥부의 길이를 측정한 결과, 알주머니 속 의 후기배아와 제 1 령 유충은 각각 $6.2 \sim 7.5 \mathrm{~mm}, 6.85 \sim 8.04$ $\mathrm{mm}$ 인 것으로 관찰되었다. 또한 알주머니를 벗어난 제2령 유 충과 제 3 령 유충의 경우는 각각 $7.48 \sim 7.90 \mathrm{~mm}, 9.42 \sim 11.74$ $\mathrm{mm}$ 인 것으로 측정되었다. 한편, 동면 직전의 아성체 (subadult) 와 번식기의 성체를 대상으로 측정한 결과는 각각 1.85 $2.59 \mathrm{~mm}$ 와 $2.35 \sim 3.70 \mathrm{~mm}$ 로 나타났다. 따라서 발생단계에 따른 광릉늑대거미 유충의 크기는 후기 배아에서 제1령 유 충까지의 증가비율보다 제 2 령 유충에서 제 3 령 유충사이의 증가비율이 보다 현저한 것으로 분석되었고, 또한 아성체의 두흉부 크기는 성체의 약 $70 \%$ 에 달하는 것으로 확인되었다.

\section{고 찰}

거미류의 발생 단계는 (1) 수정란의 배아발생 (embryogene- sis) 단계, (2) 불완전 유충단계 (larval period), (3) 완전 유충 단계 (juvenile or nymphal stage), 그리고 (4) 성체 (adulthood) 단계 등으로 구별되는데, 온도, 광량, 습도, 먹이 등에 영향을 받는 것으로 알려지고 있다(Schaefer, 1987; Foelix, 2011). 특히, 배후발생 과정은 거미의 생활사에서 매우 가변적인 발 생기간이고, 또한 그 어느 시기보다 환경요인의 영향이 큰 것으로 보고된 바 있다(Levy, 1970; Schaefer, 1987).

거미의 발생 단계는 변태를 하는 곤충류나 다른 절지동물 에 비해 비교적 단순하지만 발생 단계를 구분하는 용어의 혼란은 매우 심각한 상태이다. 이런 혼란이 야기된 주된 원 인은 연구자들이 유충 단계를 구분하기 위해 prelarva, larva, pullus, postpulllus, instar, prenymph, nymph, spiderling 등과 같은 다양한 용어를 독자적으로 사용한데서 비롯된 것으로 파악되고 있다(Canard, 1987; Downes, 1987; Canard \& Stockmann, 1993; Foelix, 2011). 실제로 유충(larva)라는 용어는 완 전 변태를 하는 곤충의 애벌레 단계에서 주로 사용되는 용 어임에도 불구하고, 이를 불완전 변태를 하는 거미류의 발 생 단계에 도입한 초기의 연구들로부터 그 원인이 제공된 것으로 추정할 수 있다.

또한, 거미류의 발생에서 부화(eclosion)라는 현상은 일반 적으로 배아로부터 후기배아로 이행하는 발생학적 증거로 해석되지만, 종에 따라 부화가 일어나는 단계가 매우 다양 한 형태로 일어나는 것으로 알려지고 있다(Downes, 1987). 대부분에 거미들은 전유충(prelarva) 단계에서 난각을 빠져 나오지만, 일부 종류에서는 유충 단계에 진입한 후 부화가 일어나기도 한다. 이러한 이유로 Vachon(1957)은 부화를 단 순히 배아단계가 종료되고 성체와 유사한 형체를 지닌 전유 충이 출현하는 전환점으로 해석하고, 거미류의 발생단계 구 분시에 부화가 발생학적 기준점이 되지 못한다는 의견을 제 시하기도 하였다.

이러한 문제점을 충분히 인식하고 있음에도 불구하고, Foelix (2011)에 의해 최근 개정출판된 "Biology of Spider" 에서조차 거미의 발생단계 구분에 대한 부정확한 개념이 여 전히 사용되고 있음이 확인된다. 즉, 난각(chorion)을 지닌 부화 직전의 배아 단계를 후기배아로, 부화된 최초의 유충 단계를 제 1 령 유충으로, 그리고 1 회의 탈피를 끝낸 개체를 제 2 령 유충으로 구분하고 있으나, 이는 거미강 (Arachnid)의 동물군에서 보편적으로 사용되고 있는 발생 단계와 상당한 괴리가 있어 더욱 혼란을 가중시키는 결과를 초래하였다.

따라서 이러한 혼란을 피하기 위해, 일부 연구에서는 거 미의 발생 단계를 자체적으로 규정하는 경우도 빈번히 발 생하고 있는 실정이지만(Liu, 2009), 최근 Robert (2005)에 의해 제시된 발생 단계의 구분에 대한 정의가 거미류뿐만 아니라, 거미강에 속하는 여러 분류군의 발생 단계에 공통 적으로 적용할 수 있는 종합적이고도 합리적인 기준인 것 으로 평가된다. 본 연구에서도 이 기준에 준하여 발생의 단 
계를 구분하였는데, 광릉늑대거미의 초기 발생 단계는 난각 을 깨고 부화가 이루어진 단계를 후기배아로, 첫 번째 탈피 (molting)를 끝낸 단계를 제1령 유충으로, 그리고 두 번째 탈피를 마치고 알주머니에서 빠져 나온 단계를 제 2 령 유충 으로 규정하고, 순차적으로 다음 단계의 유충을 규정하였다.

광릉늑대거미의 초기 발생과정을 면밀히 관찰한 결과, 부 화된 후기배아는 2 회의 탈피가 일어날 때까지 알주머니 속 에 머무른 후, 제 2 령 유충단계에서 알주머니를 벗어나 모체 의 등위로 이동함이 확인되었다. 또한 이 시기를 즈음하여 체표에 강모가 형성되었고 유충이 빠져나간 알주머니에서 는 다량의 탈피 잔여물들이 관찰되었다. 제 2 령 유충 단계는 서식 환경에 따라 약간의 편차가 있으나 일반적으로 약 9 10 일간 지속되고, 이후 탈피하여 제 3 령 유충이 되는데, 이 시 기에 흑색소반응(melanization)에 의해 체색의 갈변현상이 현저해지고 두흥부의 크기도 급격히 증가함이 확인되었다.

일반적으로 거미의 성장을 판단하는 척도로 몸 전체의 길 이(Vollrath, 1983), 갑각(carapace)의 길이(Jackson, 1978) 또 는 폭(Schaefer, 1976), 눈 사이의 간격(Jackson, 1978), 독니 (fang)의 길이(Stradling, 1978), 제1경절(tibia)의 길이(Coyle, 1985), 그리고 제 1 부속지의 마디 길이(Vollrath, 1983) 등 다 양한 기준들이 사용되고 있지만, 거미류의 경우 개체군 사 이의 크기 차이나 변이가 그 어느 동물군보다 큰 것으로 알 려지고 있다. 실제로, 왕거미과의 Nephila clavipes에서 측정 된 결과에 의하면, 섭식환경에 따라 개체의 크기나 성장률 에 큰 편차가 확인되었으며(Vollrath, 1983), 미투기거미과 (Miturgidae)의 거미를 대상으로 한 연구에서도 유충의 섭 식 상태에 따라 발생의 단계가 조절되고, 먹이의 공급주기 에 따라 탈피시기에 변화가 초래될 수 있음이 관찰된 바 있 다(Pfannenstiel, 2008).

그러나 먹이 활동을 하지 않는 후기배아나 제 1 령 유충 단 계에서는 영향이 미미할 것으로 판단되며, 다른 늑대거미류 를 대상으로 한 이전의 연구에서도 제 2 령 유충시기에 알주 머니를 벗어나 모체의 등위로 올라간다는 관찰이 이루어진 바 있다(Eason \& Whitcomb, 1965; Buddle, 2000). 또한, 후 기배아단계부터 부속지를 포함한 전반적인 외부형태는 성 체와 유사하지만, 체표의 색상이나 무늬, 그리고 강모의 유 무 등에서 현저한 차이를 보이다가 먹이활동을 시작하는 제 2 령 유충 단계에서 현저한 색소화 반응과 강모의 형성이 일 어나는 것은, 은밀한 사낭활동을 통해 먹이를 포획하여야 하 는 배회성거미류의 행동 습성으로 미루어 이들이 외부 환 경에 적응하기 위한 진화의 결과일 것으로 추정된다.

거미 두향부의 외골격은 제 1 령 유충시기를 제외한 대부 분의 발생 기간동안 탈피시에만 성장하고 평상시 (intermolt period)에는 성장하지 않지만(Vollrath, 1987), 복부는 생활 사의 전체 기간동안 부드러운 상태로 유지되고 섭식한 영 양물질을 지질이나 탄수화물, 단백질 등으로 전환하여 저장
하는 것으로 보고되고 있다(Collatz \& Mommsen, 1974). 일 반적으로 거미류의 탈피 횟수는 매우 가변적이고(Schaefer, 1976, 1987), 몸체의 크기나 환경요소, 동면 등에 큰 영향을 받는 것으로 보고되고 있다(Vollrath, 1987). 몸집이 큰 거미 류일수록 유충의 기간이 상대적으로 긴 것으로 알려지고 있 으나(Levy, 1970), 몸체와 탈피와의 상관관계는 명확히 규 정되지 않고 있는 실정이다.

거미의 중추신경계는 뇌라는 단일 신경조직의 덩어리를 형성하고, 이는 위쪽의 식도상신경절과 아래쪽의 식도하신 경절로 나뉘어진다(Babu \& Barth, 1984; Hill, 2006). 이들 신 경절로부터 수많은 신경들이 분지되어 몸 전체에 말초신경 계를 구성하고 있다. 대부분의 신경들은 거미의 다양한 근 육조직이나 감각기와 연결되어 있으므로(Babu, 1985; Weygoldt, 1985), 발생 초기의 신경분화는 보행과 관련된 부속지 나 시각과 관련된 시각기 등의 신경발달과 밀접한 연관을 지니고 있을 것으로 추정된다(Babu, 1975; Hwang \& Moon, 2003). 실제로 광릉늑대거미에서 관찰된 결과에서도, 알주머 니 내에서 별다른 움직임을 보이지 않는 후기배아나 제1령 유충의 조직에서 부속지 근육의 발달이 미비하였고, 이들 근 육을 통제하는 식도하신경절이나 부속지신경절과 연결되는 신경섬유의 발달도 미약함이 확인되었다.

반면, 알주머니를 벗어나 먹이활동을 시작하는 제 2 령 유충 의 부속지는 분절구조가 완성되고 근육조직이 발달되어, 부 속지신경절과 연결된 신경섬유의 다발도 급격히 증가되었고 시각기의 발생도 완료되어 시각신경절과 말초의 시각신경 이 급속히 분화되어 성체와 거의 동일한 조직학적 체제를 갖춘 것으로 확인되었다. 정주성거미류인 Argiope aurantia 에서도 유충이 알주머니의 실크를 딿고 나오는 원동력이 유 충이 지닌 효소의 분해력과 미세한 치아구조를 이용한 저작 력에서 비롯되며, 유충들은 알주머니를 탈출하는 시기를 전 후하여 성체가 지닌 대부분의 구조와 운동능력을 가지게 됨 을 밝힌 바 있다(Foradori et al., 2002).

\section{참 고 문 헌}

Babu KS: Post embryonic development of the central nervous system of the spider Argiope aurantia (Lucas). J Morphol 146 : 325-342, 1975.

Babu KS: Patterns of arrangement and connectivity in the central nervous system of arachnids. In: Barth FG, ed, Neurobiology of Arachnids. pp. 3-19, Springer-Verlag, New York, 1985.

Babu KS, Barth FG: Neuroanatomy of the central nervous system of the wandering spider, Cupiennius salei (Arachnida, Araneida). Zoomorphology 104 : 344-359, 1984.

Balázs K, Ferenc S: Comparison of autumn and winter development of two wolf spider species (Pardosa, Lycosidae, Araneae) having different life history patterns. J Arachnol 30 : 409-415, 2002. 
Buddle CM: Life history of Pardosa Moesta and Pardosa Mackenziana (Araneae, Lycosidae) in central Alberta, Canada. J Arachnol $28: 319-328,2000$.

Canard A: Analyse nouvelle du développement postembryonnaire des araignées. Revue Arachnologique 7 : 91-102, 1987.

Canard A, Stockman R: Comparative postembryonic development of arachnids. Memoirs of Queensland Museum 33 : 461-468, 1993.

Collatz KG, Mommen T: Lebensweise und jahreszyklische Veränderunger des Stoffbestandes des Spinne Tegenaria atrica CL Koch (Agelenidae). J Comp Physiol 91 : 91-109, 1974.

Coyle FA: Ballooning behavior of Ummidia spiderlings (Araneae, Ctenizidae). J Arachnol 13 : 137-139, 1985.

Downes MF: A proposal for standardization of the terms used to describe the early development of spiders, based on a study of Theridion rufipes Luca (Araneae: Theridiidae). Bull Brit Arachnol Soc 7 : 187-193, 1987.

Eason R, Whitcomb WH: Life history of the dotted wolf spider, Lycosa Punctulata Hentz (Araneida: Lycosidae). Arkansas Acad Sci Proc 19 : 11-20, 1965.

Foelix RF: Biology of Spiders (3rd ed). Oxford Univ. Press, New York, pp. 1-419, 2011.

Foradori MJ, Kovoor J, Moon MJ, Tillinghast EK: Relation between the outer cover of the egg case of Argiope aurantia (Araneae: Araneidae) and the emergence of its spiderlings. J Morphol 252 : 218-226, 2002.

Groome JR, Townley MA, de Tschaschell M, Tillinghast EK: Detection and isolation of proctolin-like immunoreactivity in Arachnids: Possible cardioregulatory role for proctolin in the orb-weaving spiders Argiope and Araneus. J Insect Physiol 37 : 9-19, 1991.

Hill DE: The structure of the central nervous system of jumping spiders of the genus Phidippus (Araneae: Salticidae). MS Thesis (Republ. ver.), Oregon State Univ., 2006.

Hwang HJ, Moon MJ: Fine structural analysis of the central nervous system in the spider, Achaearanea tepidariorum (Theridiidae: Araneae). Kor J Entomol 33 : 119-126, 2003.

Im MS, Kim ST: Field Guide of Korean Spider. Kunkuk Univ. Press, Seoul, pp. 162-176, 2000.

Jackson RR: Life history of Phidippus johnsoni (Araneae, Salticidae). J Arachnol 5 : 145-149, 1978.

Jacqueline K, Arturo MC: Embryonic and postembryonic morphogenesis of the visual, venom-and silk-gland system in two species of peucetia (Araneae: Oxyopidae). Eur J Entomol 92 : 565-571, 1995.

Karnovsky MJ: A formaldehyde-glutaraldehyde fixative of high osmolality for use in electron microscopy. J Cell Biol 27 : 137A, 1965.

Kim JP: Coloured Spider of Korea. Academy Press, Seoul, pp. 260290, 2002.

Laurie BM, John SR: Growth and development rates in a riparian spider are altered by asynchrony between the timing and amount of a resource subsidy. Oecologia $156: 249-258,2008$.
Levy G: The life cycle of Thomisidae onustus (Thomisidae: Araneae) and outlines for the classification of the life histories of spiders. J Zool (London) $160:$ 523-526, 1970.

Liu Y, Andreas M, Waloszek D: Early development of the anterior body region of the grey widow spider Latrodectus geometricus Koch, 1841 (Theridiidae, Araneae). Arthropod Struct Dev 38 : 401-416, 2009.

McGregor AP, Hilbrant M, Pechmann M, Schwager EE, Prpic NM, Damen WG: Cupiennius salei and Achaearanea tepidariorum: spider models for investigating evolution and development. BioEssays 30 : 487-498, 2008.

Pfannenstiel RS: Development of the cursorial spider, Cheiracanthium inclusum (Araneae: Miturgidae), on eggs of Helicoverpa zea (Lepidoptera: Noctuidae). J Entomol Sci 43 : 418-422, 2008.

Robert GB: Arachnid developmental stages: Current terminology. College of the Southwest, Carlsbad, New Mexico, USA. pp. 15, 2005.

Schaefer M: An analysis of diapause and resistance in the egg stage of Floronia bucculenta (Araneida: Linyphiidae). Oecologia $25: 155-174,1976$.

Schaefer M: Life cycle and diapause. In: Nentwig N, ed, Ecophysiology of Spiders. pp. 331-347, Springer-Verlag, New York, 1987.

Stollewerk A, Seyfarth EA: Evolutionary changes in sensory precursor formation in arthropods: Embryonic development of leg sensilla in the spider Cupiennius salei. Dev Biol 313 : 659-673, 2008.

Stradling DJ: The growth and maturation of the "tarantula", Avicularia avicularia L. Zool J Linn Soc 62 : 291-303, 1978.

Teresita CI, Jerome C: The functional morphology of color changing in a spider: development of ommochrome pigment granules. J Exp Biol 211 : 780-789, 2008.

Vachon M: Contribution à l'étude du développement postembryonnaire des araignées. Première note. Généralités et nomenclature des stades. Bull Soc Zool Fr 82 : 337-354, 1957.

Vollrath F: Relative and absolute growth in Nephila clavipes. Verh Naturwiss Ver Hamburg 26 : 277-289, 1983.

Vollrath F: Growth, foraging and reproductive success. In: Nentwig N, ed, Ecophysiology of Spiders. pp. 357-370, Springer-Verlag, New York, 1987.

Weygoldt P: Ontogeny of the arachnid central nervous system. In: Barth RG, ed, Neurobiology of Arachnids. pp. 20-37, SpringerVerlag, New York, 1985.

Wolff C, Hilbrant M: The embryonic development of the central American wandering spider Cupiennius salei. Front Zool 8 : 15$50,2011$.

\section{<국문초록>}

배회성거미류의 배후발생과정에서 형태적 분화가 행동학적 특성으로 발현되는 기전을 규명하기 위하여 광릉늑대거미 (Arctosa kwangreungensis) 후기배아와 각 발생 단계의 유충을 
실험재료로 그 조직학적 및 미세구조적 변화를 광학 및 주사전 자현미경으로 분석하였다. 난황주머니를 가진 후기배아는 부속 지의 근육조직과 신경절의 미분화로 비활성상태를 유지하며, 시 각기의 신경절과 신경의 발달도 미약하였다. 제 1 령 유충의 두흉 부에서는 미분화된 세포집단이 관찰되고 체색의 발현과 복부신 경절의 분화가 현저하였다. 먹이 활동을 시작하는 제 2 령 유충의 중추신경계에는 신경섬유가 급격히 증가되었고, 성체와 유사한 부속지의 분절구조와 시각기의 조직학적 체제가 확립되었다. 제 3
령 이후의 유충들은 탈피를 거듭하여 두흉부에서 중추신경계가 차지하는 영역이 축소되었고 독선과 근육조직, 그리고 결합조직 등의 활발한 분화가 진행되었다. 먹이활동을 시작하는 제 2 령 유 충 단계에서 부속지와 시각기의 조직학적 발생과 이를 통제하는 신경계의 분화가 완료되는 것으로 미루어, 섭식환경이 배후발생 과정을 조절할 수 있으며, 특히 시각과 부속지에 의존하여 먹이 를 포획하는 배회성거미류의 행동 습성이 형태조직학적 분화와 연관되어 있음을 확인할 수 있었다. 